\title{
The Use of Silver-Impregnated Dressings in Korea
}

\author{
Young-Joon Marco Jun \\ Department of Plastic Surgery, Seoul St. Mary Hospital, College of Medicine, The Catholic University of Korea, Seoul, Korea
}

People are wounded from time to time. These wounds can be classified into open and closed wounds according to their configuration, or acute and chronic wounds according to their duration. They can also be classified according to their depth, infection status, or originating disease.

Dressings make direct contact with a wound to accelerate its recovery while protecting it. They act to establish an appropriate environment for promoting the formation of granulation tissue and epithelization, thereby helping the wound to heal.

Since George Winter reported in the 20th century that a proper moist environment helps to heal wounds, numerous dressing materials have been developed to help create and maintain such an environment. The newly developed dressing materials are intended to overcome the disadvantages of previously used gauze dressings, including adherence to the wound at the time of removal, necessity for frequent dressing change due to absorption limitation, and lowering of wound temperature.

Silver-impregnated dressings are considered to be one of the most effective treatments for chronic infectious wounds and are particularly effective for diabetic wounds. The inflammatory phase of wound healing is easily prolonged in diabetic wounds, which are prone to infection, though of course infection is but one of the reasons for diabetic wound healing stasis. When infection does occur, it should be controlled and removed as efficiently as possible in order to prevent further prolonging and stasis of the inflammatory phase and promote wound healing. Tsang et al. [1] published a randomized controlled study, which showed that nanocrystalline silverimpregnated dressings are effective in diabetic foot ulcers. Gottrup et al. [2] published a paper on the effectiveness of applying silver-impregnated dressings on chronic wounds. As such, many studies have shown that using silver-impregnated dressings is effective for chronic wounds and infected wounds [3-10].

However, in the Korean National Health Insurance system, silver-impregnated dressings are covered by insurance only when applied to burn injuries. Moreover, using these dressings on non-burn wounds falls under the category of "arbitrary uninsured application," which means that receiving any reimbursement or payment for these dressings is punishable by law, regardless of patient consent for their use and payment. In other words, silver-impregnated dressings cannot be used on non-burn chronic infectious wounds or for infection prevention unless they are applied totally free of charge, which drastically limits their utility in Korea. With constant changes in the medical environment, including the expansion of patients' characteristics and demands, and the improved level of overall medical services together with the development of medical technologies, the demands imposed upon our National Health In-

\section{Editorial}

Received: February 1, 2019

Revised: February 18, 2019

Accepted: February 18, 2019

Corresponding author:

Young-Joon Marco Jun, M.D., Ph.D.

Department of Plastic Surgery, Seoul St. Mary Hospital, College of Medicine, The Catholic

University of Korea, 222 Banpo-daero,

Seocho-gu, Seoul 06591, Korea

Tel: +82-2-2258-6141

Fax: +82-2-594-7230

E-mail: joony@catholic.ac.kr

This is an Open Access article distributed under the terms of the Creative Commons Attribution Non-Commercial License (http://creativecommons.org/licenses/by-nc/4.0/) which permits unrestricted non-commercial use, distribution, and reproduction in any medium, provided the original work is properly cited.

(C) 2019 Korean Wound Management Society 
surance system are also progressively changing. Therefore, the health insurance system's coverage of silver-impregnated dressings should be actively discussed and conferred, so that these innovative dressings can be used for infection prevention and control in various acute and chronic wounds instead of just burn injuries.

\section{Conflict of interest}

Y.J.M.J. is the Vice President and Director of the Health Insurance Committee of the Korean Wound Management Society. No other potential conflict of interest relevant to this article was reported.

\section{Acknowledgments}

Young-Joon Marco Jun https://orcid.org/0000-0001-65372460

\section{References}

1. Tsang KK, Kwong EW, To TS, et al. A pilot randomized, controlled study of nanocrystalline silver, Manuka honey, and conventional dressing in healing diabetic foot ulcer. Evid Based Complement Alternat Med 2017;2017:5294890.

2. Gottrup F, Cullen BM, Karlsmark T, et al. Randomized controlled trial on collagen/oxidized regenerated cellulose/silver treatment. Wound Repair Regen 2013;21:216-25.

3. Meuleneire F. An observational study of the use of a soft sili- cone silver dressing on a variety of wound types. J Wound Care 2008;17:535-9.

4. Jude EB, Apelqvist J, Spraul M, et al. Prospective randomized controlled study of Hydrofiber dressing containing ionic silver or calcium alginate dressings in non-ischaemic diabetic foot ulcers. Diabet Med 2007;24:280-8.

5. Dhatariya K, Gooday C, Franke B, et al. An open, non-comparative, multicentre evaluation of performance and safety using an antimicrobial exudate transfer dressing on diabetic foot ulcers: a case series. J Wound Care 2016;25:256-65.

6. Chae SB, Jung SH, Lee SW. The effectiveness of home treatment with nanocrystalline silver product (Acticoat (TM)) on the chronic ulcerative lesion of foot. J Korean Foot Ankle Soc 2013;17:277-82.

7. Zakizadeh M, Asadizaker M, Jahani S, et al. Comparing the effect of Acticoat (TM) dressing and dressing with phenytoin cream on the healing process of pressure ulcer. Int J Adv Biotechnol Res 2016;7:1250-9.

8. Kuo CY, Wootten CT, Tylor DA, et al. Prevention of pressure ulcers after pediatric tracheotomy using a Mepilex Ag dressing. Laryngoscope 2013;123:3201-5.

9. Miller CN, Newall N, Kapp SE, et al. A randomized-controlled trial comparing cadexomer iodine and nanocrystalline silver on the healing of leg ulcers. Wound Repair Regen 2010;18:359-67.

10. Gago M, Garcia F, Gaztelu V, et al. A comparison of three silver-containing dressings in the treatment of infected, chronic wounds. Wounds 2008;20:273-8. 